\title{
Entre a perda e a queda poética: Desterro, de Camila Assad, ou como construir colectividade a partir de uma escrita por apropriação
}

Resumo: O presente artigo tem como objeto de análise o livro de poemas Desterro de Camila Assad, publicado em 2019 pela Editora Macondo. A leitura proposta parte da polissemia do título para examinar os três eixos que se sobrepõem na obra: cidade, mulher e poema. Em primeiro lugar, examinamos a incorporação de elementos visuais, espaciais e traços de oralidade, para aprofundar em um tipo de escrita que pretende construir poemas, ao mesmo tempo que cidades, a partir de uma perspectiva feminina. Em seguida, concentramos nossa análise nas técnicas de escrita utilizadas pela autora: argumentamos que, através dos vários processos apropriação e transcrita, a poeta organiza novas coletividades e reivindica seu lugar, como também o de suas predecessoras, tanto no campo literário como no espaço público. Obra indisciplinada, ousada e lúdica, Desterro apresenta um périplo literário em que, despois da perda e da queda, a voz poética sai reforçada e ganha um corpo social através da assimilação (explícita) de leituras e escutas.

Palavras-chave: Desterro, cidade, Camila Assad, poesia brasileira contemporânea, escrita por apropriação

Abstract: This article examines Camila Assad's poetry book Desterro, published in 2019 by Editora Macondo. Departing from the polysemy that its title suggests, our analysis focuses on the three main axes articulated in Assad's work: cities, women, and poems. First, we call attention to the role played by visual, spatial and oral marks in order to unpack a type of writing that seeks to build poems, as it builds cities, from a feminine perspective. Then, after reflecting on the writing techniques used by the author, we claim that through various processes of appropriation and transcreation, Assad organizes new collectivities while securing a place for her, as well as her predecessors, both in the literary realm and the public spheres. As an undisciplined, audacious, and playful work, Desterro proposes a literary journey that embraces the loss and fall of the poetic voice to ultimately attain a social body through the (explicit) assimilation of reading and listening practices.

Keywords: Desterro, city, Camila Assad, brazilian contemporary poetry, uncreative writing 
A palavra "desterro" sugere separação, banimento, estranhamento e/ou resistência estratégica em relação a determinado ambiente social e território, mas também a condição de não pertença ou exclusão na que vive uma pessoa ou grupo com relação a um meio hostil. Após Cumulonimbus (Quintal Edições, 2017) e eu não consigo parar de morrer (Editora Urutau, 2019), Camila Assad embarca em uma viagem de exploração poética que busca, na privação e na atitude de sair do isolamento, reivindicar um espaço público para as mulheres. Lançada na FLIP e publicada pela Edições Macondo, Desterro (2019) é uma declaração de princípios na que a autora de Presidente Prudente (SP) demanda algo mais que "um quarto só seu".

De certa forma, a condição de exclusão que tem definido a experiência de tantas mulheres, ainda hoje marginalizadas na hora de participar do espaço urbano, da escrita e, de maneira geral, das funções próprias do corpo social, já aparece perfilada nos quatro versos de "Prisão", de Cecília Meireles (1901-1964), escolhidos para introduzir a antologia. ${ }^{1}$ Os três eixos que atravessam Desterro - poesia, mulher e cidade - pretendem, ousada, indisciplinada e ludicamente, desfazer a condição de isolamento e ostracismo que condenam aqueles corpos excluídos. Mas vamos por partes.

A obra mostra-se ousada e sem dificuldades de abraçar uma escrita por apropriação que, além de estabelecer um diálogo, sobretudo com a tradição brasileira e anglo-saxã, encontra cumplicidade em escritores e escritoras contemporâneas que preenchem de significado esses lugares por muito tempo desabitados. Nesse sentido, Desterro abre o sulco profundo do silêncio das autoras que, ao longo da história, contribuíram a expandir tanto os espaços públicos quanto os espaços da escrita.

Este é um livro indisciplinado na medida em que integra e experimenta, de maneira consistente, com as dimensões espaciais e visuais do poema. Além das ilustrações de Ana Brandão, que introduzem cada uma das cinco partes em que se divide o livro e servem de imagem para a capa, os vários desenhos, gráficos, figuras geométricas, espaços em branco e quadros informativos, convenientemente espalhados pelas páginas, intervém nos textos e somam camadas de significados. O corpo do poema toma forma, ocupa espaço, e sustenta-se em outros elementos para além do logos e, por tanto, do dizível. Também, como já mencionamos, Desterro revela-se como uma obra lúdica por serem o jogo, o divertimento e o humor elementos aglutinadores que, no entanto, mal escondem uma crítica mordaz aos vários sistemas de legitimação expostos. Com efeito, a oralidade desempenha um papel importe neste jogo de vozes no qual, de forma progressiva e dando passos certeiros, a autora constrói a coletividade esperada.

Na primeira parte de Desterro, intitulada "Construir cidades significa também uma forma de escrita", Assad apresenta os fundamentos daquilo que, por vezes, toma a forma de ensaio em prosa poética. Nos onze textos enumerados, a maioria sem título, a poeta conjuga estas duas formas de criar, colocando tijolo sobre tijolo, juntando letras que seguem formas geométricas para formar palavras, e com elas frases, poemas e, portanto, discursos. O primeiro texto já apresenta a chave para entender estes processos de criação 
simultâneos e convergentes: ambos, escrita e construção, devem ser entendidos como trabalhos coletivos impulsionados pela memorização. "É como se a cidade fosse um imenso alfabeto" (Assad 2019: 14) e essa consciência permitisse "ao espaço da cidade se encarregar / de contar sua história" (idem: 15).

A modo de rito de passagem, a obra começa com algumas reflexões teóricas e gerais sobre a arquitetura para, pouco a pouco, dar espaço à voz fragmentada da poeta: "falo três idiomas e meio"; e também ao corpo que habita o espaço partido: "Já morei em cinco cidades e meia" (idem: 13). A cidade - algumas vezes o Rio de Janeiro, outras vezes São Paulo, ou ainda um conceito vago ou lugar qualquer esvaziado de toda especificidade - será o marco escolhido para exibir as desigualdades que persistem no acesso a serviços e bens culturais. A esse respeito, a poeta nos lembra do seguinte:

Mesmo quando a mulher acessa o espaço público, esse mo-/ vimento muitas vezes se resume em uma espécie de expansão / da função do espaço privado, como na frequência maior em/ mercados, farmácias, escolas, postos de saúde, ressignificando / os espaços públicos como espaços públicos como espaços de adequação à manuten- / ção do lar. (idem: 17)

Neste fragmento, vemos como a tradicional divisão de papéis de gênero tem limitado as funções sociais das mulheres com respeito ao cuidado dos outros. Enquanto que para os homens existe uma dicotomia que permite dissociar o espaço público do privado, as mulheres se viram forçadas a justificar seus movimentos em uma espécie de continuidade que expande o lar também fora de casa.

Não apenas como perspectiva, mas como tema e condição da escrita, o gênero e a classe socioeconômica articulam a história que a autora quer contar: "há apenas uma história e três lados. Há sempre uma história, / e ela sempre termina como eu quero" (idem: 16). No contínuo processo de "produção e reprodução" (idem: 17), tanto do espaço da cidade como do poema, Assad toma impulso para, de forma assertiva, reivindicar um corpo autoral feminino que cria e se expande. Aludindo não somente à sua capacidade, mas, sobretudo, à sua escolha de quando gerar, declara: "Agora você se / muda pro meu ventre, agora eu não posso ver você de novo, / agora sou eu que decido a hora de dar à luz" (ibidem).

Desse modo, este ensaio pretende examinar Desterro a partir de elementos visuais e orais presentes na obra para, através deles, aprofundar na curadoria autoral ou assimilação de leituras que propõe Camila Assad. A minha análise sugere que há um cruzamento entre a sequência da perda da auréola e a queda da poeta, e a construção de uma voz baseada em uma escrita por apropriação. A incorporação de técnicas da transcritura e de uma escrita recreativa terá como objetivo construir uma coletividade e, em última instância, tornar essa coletividade visível no campo literário e no espaço urbano. 


\section{0 périplo de Tereza em tom de aplicativo}

Tereza aparece no poema número seis, embora pouco sabemos dela: tem três filhos, trabalha no supermercado e vende água e biscoitos na rua. Ela é uma mulher trabalhadora que, todos os dias, pega quatro ônibus e se desloca por mais de duas horas e meia. Como tantas outras pessoas da classe trabalhadora, mora longe "da área nobre da cidade", concretamente a " 45 quilômetros". O hipotético trajeto de Tereza "a pé, de ônibus e de metrô para chegar ao mar" demoraria entre quatro e cinco horas (idem: 18, 19).

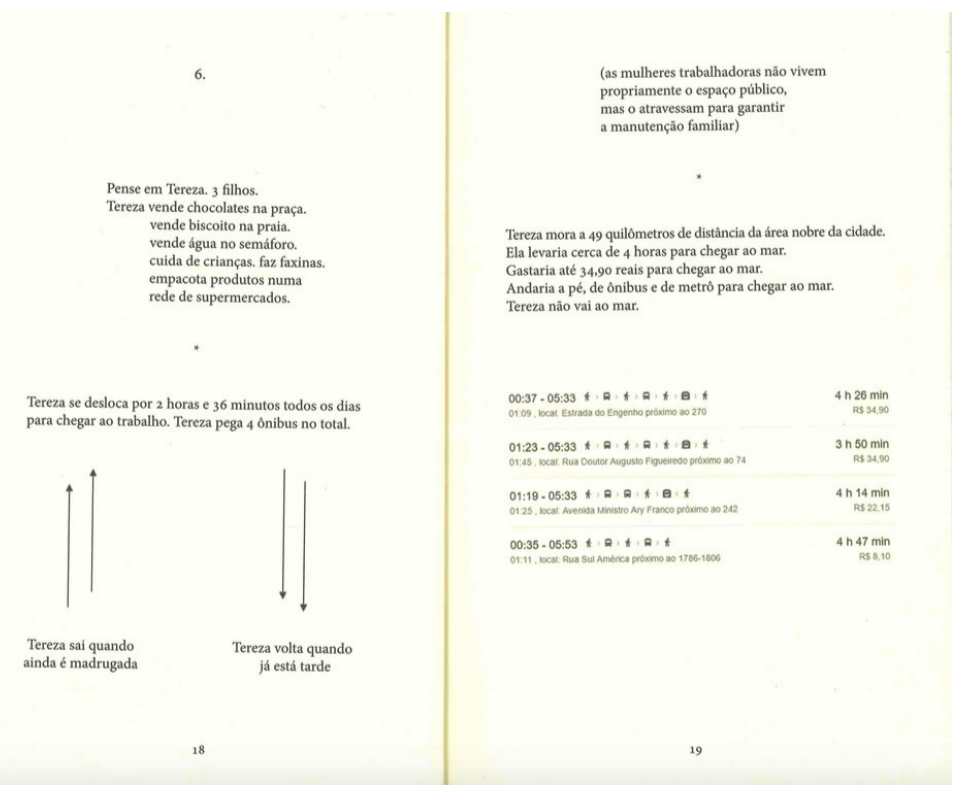

A captura da imagem de um aplicativo de mapas ilustra quatro das opções que Tereza tem. Os preços dos trajetos oscilam em função da duração dos mesmos, o que, por outro lado, não os torna mais atraentes. O que sim chama a atenção é a hora de saída. Para ver o amanhecer perto do mar, o longo trajeto exigiria que Tereza saísse de madrugada e passasse a noite sem dormir, somente se deslocando.

Primeira conclusão: "O mar está tão longe, o mar / está tão caro / o mar não é / para todos / para todas" (idem: 20). A poeta se refere a um ideal de cidade, cuja finalidade seria "ofertar ao ser humano condições de viver com dignidade" (ibidem), onde todos e todas pudessem ser "destinatários de políticas urbanas que acolhessem as diferenças" (ibidem) e "permitissem sua presença em condições de intervir e usufruir igualitariamente do espaço urbano" (ibidem). Como poetizar o deslocamento do espaço urbano perante tal situação de precariedade? 
Segunda conclusão: "É mais difícil ser Tereza do que ser Pagu" (ibidem). A alusão à figura da poeta, artista multifacetada, tradutora, jornalista e dramaturga Patrícia Galvão, Pagu (1910-1962), bem poderia responder a uma reinvindicação do legado intelectual da escritora paulistana para além de seu papel como musa do modernismo brasileiro. No entanto, é bem provável que a estreita ligação que guarda a memória de Pagu com a cidade de São Paulo, o ativismo político, que fez com que ela fosse presa várias vezes durante a ditadura de Getúlio Vargas (período da ditadura), e o seu pertencimento à classe alta cultivada, sejam informações relevantes a ser considerados nesta comparação.

Enfim, é inegável que a figura de Tereza representa a falta de acesso de determinados sectores da sociedade (neste caso, mulheres trabalhadoras da periferia) aos espaços de lazer da cidade. Como vemos, além do plano textual, esta denúncia se sustenta na forma em que palavras e imagens interagem no espaço da página. A incorporação de elementos visuais, setas de ida e volta, ícones de meios de transporte, e informações do tempo e custo das opções de deslocamento, reforçam a ideia de que muitas mulheres "não vivem/ propriamente o espaço público / mas o atravessam" (idem: 19). Basta uma olhada rápida à lenda do aplicativo Google maps para entender por que "Teresa não vai ao mar" (ibidem).

A experiência da mulher na cidade e seu dificultoso périplo até chegar ao mar servem de pretexto para desenvolver uma teoria que desmonta o conceito de flâneurie e invalida por completo a figura da flâneusse. A adaptação e reescrita da paradigmática cena da "perda da auréola", convertida, desta vez, em um hilariante diálogo entre duas senhoras brasileiras, chega precedida pela riscada da famosa passagem onde Baudelaire explica o conceito de flâneur. ${ }^{2}$ 
O texto riscado enfatiza que para o perfeito flâneur "é um imenso júbilo fixar residência no numeroso, no ondulante, no movimento, no fugidio e no infinito. Estar fora de casa e, contudo, sentir-se em casa onde quer que se encontre, ver o mundo, estar no centro do mundo..." (idem: 26). Mas, logo depois desse texto, lemos a seguinte declaração, em maiúsculas: "A ARTE DE FLANAR NÃO É NENHUM MISTÉRIO / SE VOCÊ É MACHO / BRANCO / RICO / HÉTERO”.

Pensar em Tereza à luz da figura boudeleriana do flâneur nos remete tanto à representação como à recepção, e sabemos que toda recepção implica uma resposta. Em Escrever sem escrever (2019), Leonardo Vila-Fortes cita o filósofo tcheco Vilém Flusser e aponta que a etimologia de "escrever" vem do latim scribere, que significa riscar, criar uma marca sobre certa superfície. ${ }^{3}$ De maneira muito explícita vemos como a poeta reproduz o fragmento original e convida, em sua versão traduzida, ao jogo das "leituras escolhidas" (Vila-Fortes) ou da "escrita assimiladora" (Flávio Carneiro). Como se de uma pichação se tratasse, Assad deixa um rastro de sua passagem por vários textos canônicos e, com esse gesto, marca seu território com uma mensagem de protesto.

Assim, a elaboração dos poemas 6 e 10 segue, o que poderíamos considerar, princípios de curadoria como experimentação. Escrever sem escrever argumenta que a função da escrita por apropriação seria a de reunir leituras e transformá-las em "um corpo que não deve ser entendido como um corpo de doutrina, mas como o próprio corpo de quem escreve, daquele que soube ler e montar o que leu. Escrever seria apossar-se de uma verdade particular" (Vila-Fortes 2019: 53). Nesse sentido, Assad incorpora para si textos e hipertextos que pertencem tanto ao âmbito do literário como do não literário para denunciar o vazio que envolve a representação de subjetividades femininas como a de Tereza. O silêncio na escrita é também o silêncio do poema e, desse modo, a apropriação de (hiper)textos parece sugerir um gesto performático através do qual a autora confronta o público leitor com as seguintes questões: como declamar um texto riscado? E as informações de um aplicativo de mapas? Como dizer este poema, incorporando todos os elementos visuais, sem explicá-lo? Em definitiva, a poeta explora as possibilidades ao seu alcance para expressar o não dizível, o que ficou fora do poema. A partir da precariedade que define a trânsito de mulheres na cidade, Camila Assad reclama para si o direito de ocupar um lugar literário como sujeito da escrita. Portanto, será no desempenho da escrita por apropriação, que a autora assentará as bases para que um corpo coletivo ganhe presença, também em relação à cidade.

\section{A perda da auréola}

"Observar os pontos que estão a meu redor", título da segunda parte do livro, convida leitores e leitoras a prestar atenção ao entorno. Porém, a paisagem não é mais contemplativa, onde seria possível se extraviar ou ainda um plano de fundo que espelha nossas complexidades como sujeitos pós-modernos. Camila Assad recria o encontro com o outro no espaço dinâmico da página em branco, tela onde vários elementos interagem, se 
movimentam, transformam e são transformados com o fim de (pelo menos tentar) burlar a solidão que espera "em qualquer esquina / de qualquer cidade". ${ }^{4}$
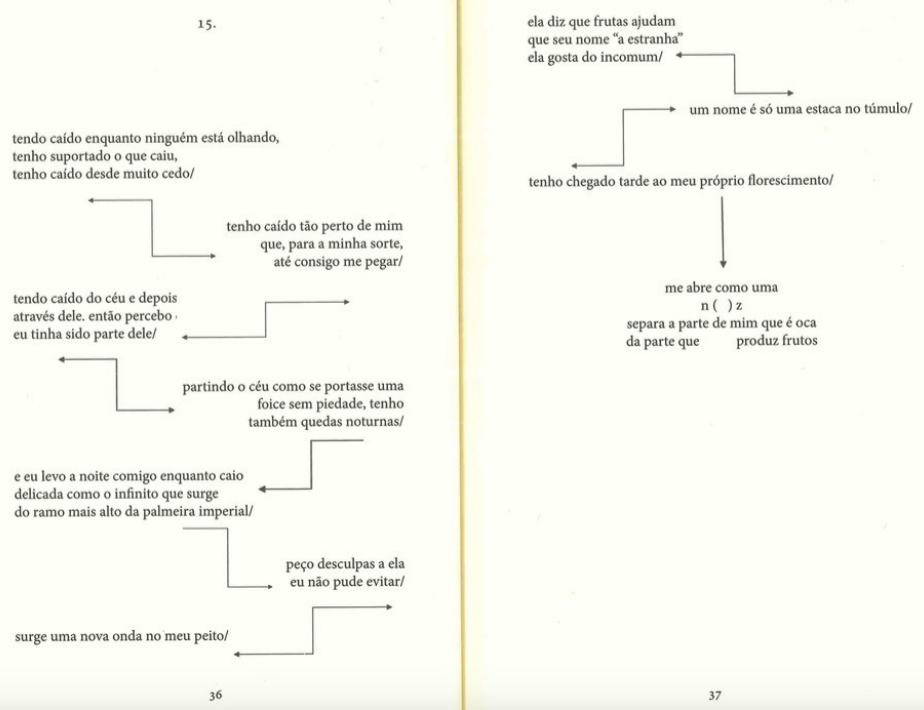

O poema 15 conjuga movimento e gravidade, crescimento e queda da poeta que se pensa dentro e fora do tempo. Como serpentes deslocando-se horizontalmente, setas e versos espalham-se em várias direções, sugerindo uma sequência, mas não necessariamente uma ordem. No entanto, o poema é também descenso. As setas e palavras impressas no papel formam escadas que podem - e talvez devam, se atendemos o sentido que marcam as pontas das setas - ser percorridas em ziguezague. A última reta, única completamente vertical, aponta para baixo. A queda final desencadeia uma quebra da que resulta o vazio da página em branco e nos leva novamente ao primeiro verso: "Tendo caído enquanto ninguém está olhando / tenho suportado o que caiu, / tenho caído desde muito cedo" (Assad 2019: 36). A voz da poeta situa-se depois da queda, uma queda imperceptível ao olhar do outro, para, em um tempo suspenso, pensar-se.

No segundo segmento, o desdobramento do eu poético adquire matizes existenciais: "Tenho caído tão perto de mim / que, para minha sorte, / até consigo me pegar". ${ }^{5}$ O verbo pegar, em sua forma pronominal e reflexiva, é celebrado, não sem ironia, como realização pessoal. "Até consigo me pegar" pode ser entendido no duplo sentido: como apegar-se, valer-se, agarrar-se a si mesmo e, ao contrário, como briga ou desentendimento entre as diferentes partes de uma unidade. Então, a poeta confessa que o ponto de partida não é outro que "o céu", sendo também a superfície pela qual se desliza levando "a noite" consigo. Após o momento de desdobramento corporal, pouco antes do desfecho do poema, 
vemos como a voz autoral se libera do nome próprio e comum, [“um nome é só uma estaca no túmulo"].

Observadora, protagonista e, inclusive, diríamos que causante da quebra, a poeta sabe que, na queda, ou no cair, aguarda o florescimento, a abertura que encontra a sua correspondência na grafia que acompanha a palavra noz: "me abre como uma/ n ( ) z / separa a parte de mim que é oca / da parte que produz frutos" (idem: 37). A última seta representa a queda definitiva, aquela que já não permite nenhum avanço. $O$ trajeto vertical, de cima para baixo, sugere, de certa forma, o não desvio entre o ponto de chegada e o de saída, mas será? Partindo do etéreo e das alturas, a poeta chega, após a queda, ao chão. Na colisão com o solo firme, a casca quebrada ficará do lado, e o fruto, uma vez fora, se entregará ao mundo. Será a partir deste momento que Camila Assad entrará em diálogo com suas predecessoras, revisando e reescrevendo trechos de textos originais com ternura, humor e sem esconder a sua admiração. Entre os autores e autoras revisitados, destacam-se Lydia Davis, Charles Bernstein e Ana Cristina Cesar. Assim, ao reunir essas leituras, ainda que Assad não encontre uma voz poética rigorosamente original, alcança uma voz própria. Voz, noz, nóis.

\section{Diálogos urbanos e transcritura poética}

"Diálogos urbanos e/ou escutas por acidente", título da terceira parte do livro, propõe um percurso marcado, em primeiro lugar, pela distância (medida em passos, quilômetros e quadras), em segundo lugar, pelo tempo (anos), e, finalmente, pelas plataformas de expressão como o livro ou a internet. As setas descendentes passam da verticalidade inicial e da linha reta à progressiva ondulação e transversalidade, sendo ocasionalmente bidirecionais. Os dez textos-vinhetas de extensão variável que conformam o longo poema número 19, encerram diálogos, reflexões, notícias e cenas que, pelo geral, e mesmo assomando eu poético, serão sempre anônimas. ${ }^{6}$

Um tom espontâneo impregna os textos que, como se fossem instantâneos cotidianos, constroem uma sorte de coletividade articulada entre o espaço público e o privado. "Se nóis e por nóis quem será contra nóis?" [a ênfase é minha] pergunta a poeta (idem: 48). A oralidade, presente em vários momentos ao longo da obra e insinuada no diálogo anterior entre X e Z, reaparece de forma explícita na grafia do pronome pessoal para, em forma de gíria, marcar um pretendido corpo social. ${ }^{7}$ Nos vários encontros entre a palavra dita e a palavra escrita, assim como na simultaneidade de vozes, a poeta incorre com a importante questão de quem se apropria de que, e com que finalidade. Desse modo, a não originalidade revela-se como uma das principais marcas estéticas de Desterro, ao mesmo tempo motor criativo e elemento desestabilizador que questiona as bases que sustentam a tradição literária.

As diferentes setas sugerem movimento, errância, um flutuar na consciência e na atenção que aproxima leitores e leitoras às subjetividades de outros e outras. Camila Assad introduz o espaço "dentro dos livros" ao reproduzir (sem especificar) um trecho de Antonio 
(2007), romance da escritora Beatriz Bracher. A voz da protagonista do romance intervém in medias res para referir a cidade nos seguintes termos: "e São Paulo não perdoa você, esfrega na cara / o que você não consegue ser". Ao mesmo tempo, "ela dizia que só em / São Paulo é que se é alguma coisa" embora "nossos passos / são triturados, sobram ruinas, a miséria esteriliza tudo a nossa / volta" (idem: 49). A distância percorrida, em contínuo fazer e desfazer, pulveriza todo olhar romântico com respeito à construção de poemas, de mulheres e de cidades. O texto conclui com uma única certeza: "essas janelas soldadas nos protegem do barulho, da fumaça / e do suicídio, os papeis se invertem / os ratos somos nós" (idem: 50).

A partir de uma escrita assimiladora, a poeta interfere sutilmente e destaca uma série de palavras que, ao serem descoladas do texto, formam uma coluna à direita do parágrafo: “quebradas", “carros e”, “anos”, “portas”, "cinzas”, "os ratos somos nós” (idem: 50). Lidos verticalmente, estes sintagmas podem, dentro do trecho previamente recortado e despojado do contexto original, formar outro texto com significado próprio. Desse modo, Assad deambula pelas ruínas do underground ingrato que propõe o trecho do romance de Beatriz Bracher para, de forma muito sutil e abraçando o ethos "cortar, copiar e colar", aludir a um tipo escrita poética baseada no processo de reciclagem e reelaboração de textos. O segmento destacado em itálico imediatamente a seguir, leva-nos ao espaço da internet e, ainda no campo literário ligado à realidades urbanas, apresenta, no centro da página, a seguinte notícia (real):

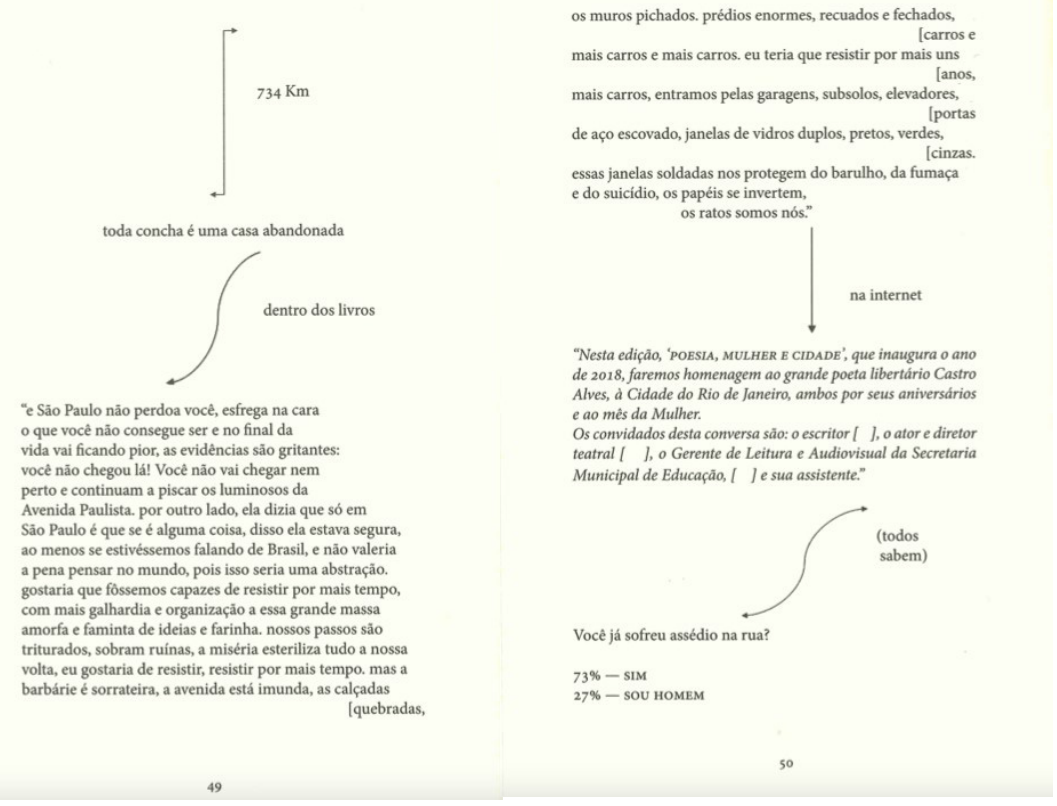


Na metade inferior da página 50, lemos como a edição de 2018 da Conversa Literária intitulada "POESIA, MULHER E CIDADE", celebrada presumivelmente no mês de março, pretende comemorar o aniversário do nascimento do poeta Castro Alves, a fundação da cidade do Rio de Janeiro, e o mês da mulher. Chama a atenção que entre os convidados, a única mulher intelectual presente na conversa parece ser a assistente do representante da Secretaria Municipal de Educação.

Desta vez, a intervenção da autora consiste em apagar os nomes dos homens que participam do evento - um escritor, um ator e diretor teatral, e um representante da Secretaria Municipal de Educação -, e deixar um espaço em branco entre aspas ao lado do cargo de cada um. A dissonância entre o objetivo do evento e a realidade que comunica a notícia evidencia um grande paradoxo: a ausência de mulheres em um evento literário que diz homenageá-las. Esta contradição aparece reforçada pelo fato de que o nome da assistente do Gerente de Leitura e Audiovisual não precisa ser apagado, já que não chegou a ser incluído em um primeiro momento.

Desse modo, vemos como o combo “POESIA, MULHER E CIDADE” apenas serve como propaganda bem-intencionada e desonesta. Mesmo quando chamadas a ser protagonistas, com frequência e ainda hoje, estas três categorias epistemológicas são minimizadas ou desestimadas como conjunto no campo literário. Depois de rememorar, em prosa epistolar, uma viagem ao Rio de Janeiro anos atrás, a poeta termina esta seção voltando à questão do silêncio no poema, e à dor que causa esse silêncio. No último verso, em referência à "arte de rua pulverizada / nos becos dizendo: / Destroy what destroys you" confessa, "mas eu me destruo" (idem: 53 ). ${ }^{8}$ Neste gesto, a voz da poeta implode, mas não desaparece, muito pelo contrário, se multiplica e cresce nas vozes de outras e outros.

Os projetos poéticos baseados na apropriação de textos e transcritura contam com uma longa trajetória na literatura brasileira. Sem aprofundar muito nesta questão, apenas referir a seguinte frase de Oswald de Andrade que, baseada em um jogo fonético, exemplifica à perfeição o processo de transferência que experimentam as palavras que passam do meio ouvido (e entendido) ao meio escrito (e lido): "a gente escreve o que ouve- não o que houve". ${ }^{9}$ Aplicado ao campo dos estudos do romance, Marília Librandi-Rocha destaca nesta enunciação uma diferença crucial entre a escrita literária de invenção (de "descoberta" e "transposição") e a escrita histórica (do que houve) e define o conceito "escrita de ouvido" a partir de três supostos: um impulso musical não mimético; um multilingualismo sonoro que considera a literatura como língua franca cosmopolita; e, a que mais nos interessa, o espaço de escuta que rompe com as dicotomias letrado/não letrado; literaturas/culturas orais; fala/escrita (Librandi-Rocha 2015: 133).

Sobre esta questão, após analisar os procedimentos experimentais explorados pelo norte-americano Kenneth Goldsmith, ${ }^{10}$ Vila-Fortes nota a perda de funcionalidade e de temporalidade que propõe a transcritura. De acordo com o pesquisador e artista, o deslocamento espacial e temporal de elementos verbais, que passam de meios como o rádio ou a rua para o livro, questionam os critérios de curadoria e a ressignificação de elementos 
descontextualizados e reproduzidos com propósitos estéticos concretos. Assim, a obra não parte de si, mas desde fora (Vila-Fortes 2019: 145).

Exemplos mais recentes como Na cidade aberta (1993), de Alberto Pucheu, propuseram pesquisas poético-sonoras que consistiam em coletar frases anônimas sobre um tema concreto, neste caso, o transporte público na grande cidade. Grande parte da materialidade textual do poema foi composta a partir de chamamentos de vendedores ambulantes que anunciam seus produtos e promoções. Quase duas décadas depois, seguindo procedimentos bastante parecidos, Verónica Stigger lança Delírio em Damasco (2012), reunião de falas ou "dessas frases ouvidas aqui e ali", em torno à "tríade sangue, sexo e grana", que pretende construir uma "arqueologia da linguagem do presente, em busca da poesia inesperada". ${ }^{11}$ Estas poéticas da reciclagem trazem à colação temas importantes como a materialidade do texto ou a visibilidade social do grupo anunciador mas, sobretudo, alude à despossessão na escrita. Em base à analise da obra de Alberto Pucheu, Silveira Ribeiro nota como esta forma de escrever "despossuída" resulta "do processo de renúncia à posse das palavras, ao rigor da identidade e da assinatura, ao conforto do pertencimento" (Silveira Ribeiro 2017: 202). Em grande medida, poetas como Assad, Pucheu e Stigger retraem-se, "quase se retira[m] da cena, transformando-se em agenciador[es] de palavras e sons outros, alheios, muitos dos quais nunca seriam ouvidos" (ibidem).

Já "Objetos verbais não identificados: um ensaio de Flora Süsssekind” (2013) destaca, por exemplo, as obras de literatura brasileira contemporânea que se afirmam na multiplicidade de vozes e na sobreposição de registros, modos expressivos e elementos não verbais diversos. Tomando emprestado o termo cunhado por Christophe Hanna, Süsssekind identifica um conjunto significativo de textos sustentados na transferência material, cujo foco reside em uma série de experiências corais marcadas pelas operações de escuta e pela constituição da multiplicidade de falas e ruídos. Ela também afirma que "nas formas corais, há uma interrogação simultânea tanto da hora histórica quanto do campo mesmo da literatura" (não numerado). ${ }^{12}$

Voltando à obra que nos ocupa, talvez o fato de Desterro responder a procedimentos de apropriação e transcritura, ou seja, de oferecer uma série de leituras (e escutas) assimiladas, não seja particularmente original, pois, em maior ou menor medida, toda obra literária o faz. Porém, pensamos que é precisamente no diálogo explícito entre referentes literários, sociais e urbanísticos que a poética de Assad toma força. Nessa busca por traçar novas cartografias urbanas a partir da multiplicidade de elementos visuais, sonoros e afetivos, a poeta conecta com movimentos de vanguarda como a International Situationniste, cuja teoria da "deriva" já mostrou preocupações semelhantes.

Nas palavras de Debord, "le concept de dérive é indissolublement lié à la reconnaissance d' effets de nature psychogéographique, et à l'affirmation d'un comportement ludique-constructif, ce que l'oppose en tous points aux notions classiques de voyage et de promenade" (Debord 1956: 19). ${ }^{13}$ Assim, a prática da "deriva" consistia em deambular pela cidade e também pelas periferias da cidade, ora em grupos reduzidos, ora em 
solitário, com o fim de elaborar um mapa psicogeográfico (temporal, espacial, psicológico e artístico) das áreas exploradas e percorridas. Em última instância, buscava liberar o ser humano contemporâneo da alienação e ócio arquetípicos da burguesia.

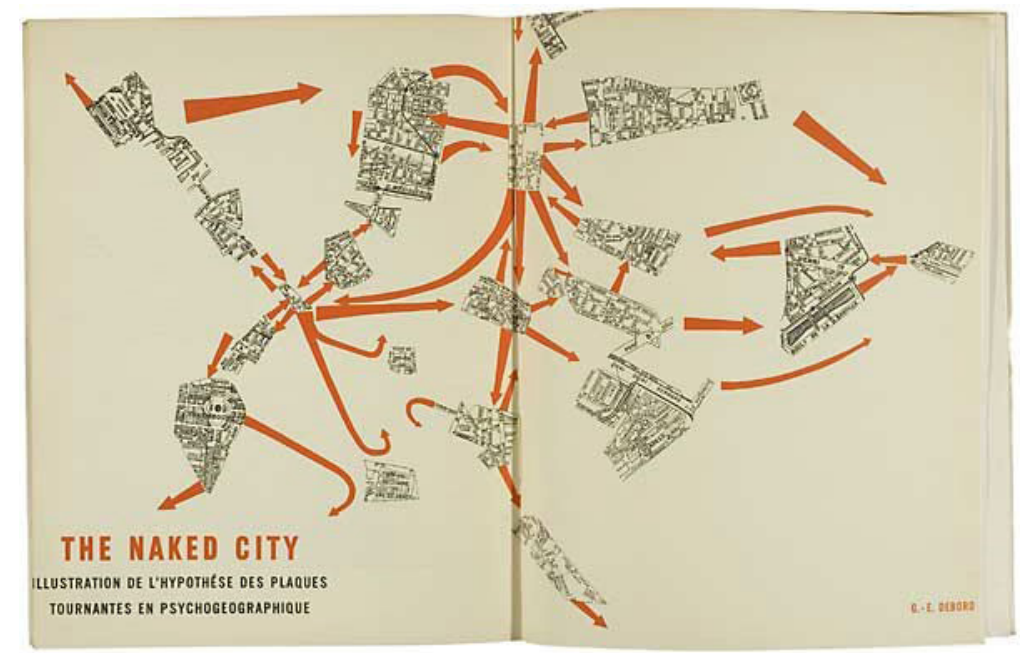

Como vemos, Debord rearranja o mapa turístico de Paris, fatia os bairros e liga eles aleatoriamente para propor novos itinerários guiados pelo acaso com o fim de alterar as trajetórias humanas automatizadas. ${ }^{14}$ O mapa The naked city (1957) surge, por sua vez, como resultado de múltiplas apropriações: além dos fragmentos de mapas da Guide Taride, de Paris, Debord toma emprestado o título do filme de Jules Dassin (1948), que alude ao título livro de uma fotografia que Weegee dedica às ruas de Nueva Iorque em 1945. De forma semelhante, a deriva que propõe Assad surge como um jogo de sucessivas apropriações e fragmentação de fontes (literárias e cotidianas). Contudo, em lugar de propor mapas baseados no "método de propaganda" e no acaso, o recorte que faz a poeta possibilita a construção de cidades polifónicas que transitam entre o individual e coletivo, esta vez com a mulher como centro.

Antes do posfácio escrito por Paulo Ferraz, e da citação de Samuel Beckett que conclui Desterro, a autora refere a esse coro de referências que a acompanham na travessia, um grupo heterogêneo de nomes que, como todo elenco no fim de uma peça teatral, entra uma última vez em cena para se despedir do público e se fundir no aplauso. Entre outros (não mencionados neste ensaio), Carlito Azevedo, Elisabeth Bishop, Gertrude Stein, Giorgio Agamben, Italo Calvino, Le Corbusier, Lewis Caroll, Rebecca Solnit e Yi-Fu Tuan, surgem em uma sequência de descontextualização e recontextualização para, junto com a poeta, levantar uma casa que aspira a ser poema, quando já é obra. 


\section{Escrita recreativa, a casa do poema}

Uma vez assumida a perda, e depois da queda, a poeta abre-se ao mundo e entra em diálogo com autores e autoras que marcaram (ou riscaram) o caminho antes dela chegar. O poema 17, dividido em duas partes, assume o estilo conciso da estadunidense Lydia Davis e mexe com o espaço que ocupam os significantes dentro das frases enunciativas. Vejamos a primeira parte do poema:

\section{[LYDIA DAVIS REVISADA]}

Debaixo de toda essa limpeza o chão está na verdade muito sujo.

(Assad 2019: 40)

Vemos como, além de traduzir o texto enunciado por Davis - "Under all this dirt the floor is really very clean"15 -, Assad inverte a ordem dos referentes para mudar por completo o sentido da oração. Este simples jogo de contrários, que troca "limpeza" por "dirt" e "sujo" por "clean", mantém a estrutura e as palavras originais, mas, no processo de recontextualização, assume a possibilidade de mudar a mensagem. Em um giro de 180 graus, a língua veicular e o hemisfério de recepção do texto redefinem o marco de referência, a função e o horizonte evocativo da frase que, na versão da paulista, deixa entrever uma crítica política e social direta.

A segunda parte do texto rescreve o poema "Recuperação da adolescência", incluído em Cenas de abril (1979):16

\section{[ANA CRISTINA REVISADA] \\ É ainda mais difícil ancorar o espaço num navio. \\ (ibidem)}

Em resposta à premissa inicial, a poeta troca "navio" por "espaço" e, nesse movimento, desestabiliza o objeto a ser ancorado. Como podemos notar, o foco na versão revisada de Assad recai sobre o espaço, elemento que se articula ao longo da obra. A palavra "desterro", no título, refere-se, assim, a um périplo pela cidade líquida ${ }^{17}$ e pelas águas de uma tradição poética cada vez mais abrangente. A reescrita de textos alheios, baseada na "escrita não criativa" ou "escrita recreativa", como propõe Vila-Fortes, dá lugar a uma voz poética cuja força se caracteriza pelo humor, a ternura e a humildade. Sem reverências desnecessárias, a poeta se reconhece nestes versos que servem de base para levantar edifícios, traçar planos de cidades e construir casas.

Em "What makes a home a home?", Assad explora, "depois de Charles Bernstein", o conceito de casa como lugar. Reproduzindo a estrutura do poema ao que alude, "What makes a poem poem?", escreve: 


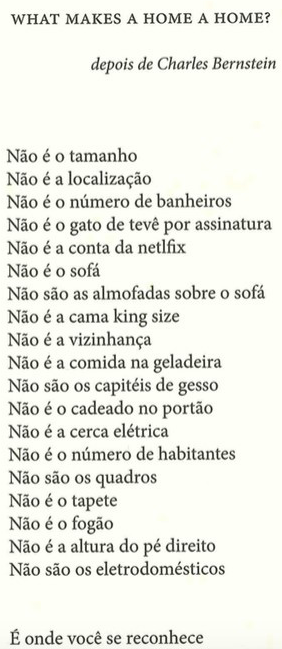

Nesta reelaboração poética que troca o poema pela casa, a oralidade pela escrita, e o minuto pela página, Assad decide manter o título em inglês e uma estrutura baseada na negação: entre outras coisas, a casa não é o tamanho, a localização, o cadeado no portão, ou os eletrodomésticos. Se a condição para o poema ser poema, de acordo com Bernstein, é o "timing" - palavra de difícil tradução, que alude ao período de tempo ou momento em que algo acontece, mas também à sincronia, elaboração e controle das coisas em relação ao tempo -, a condição da casa no poema da brasileira privilegia uma relação perceptiva e emocional do sujeito com o espaço.

Em "What makes a poem poem?", o estadunidense associado com o movimento Language poetry causa espanto ao interromper a sua declamação com o ruído do alarme do cronômetro, som que marca o final do poema. ${ }^{18} \mathrm{O}$ último verso, na versão de Assad, conclui: "é onde você se reconhece" (idem: 41). A vaga e única certeza que nos oferece incide na percepção: assumir a própria imagem passa a ser condição necessária para se encontrar no lugar. Cidade, poema e casa existem como categorias ontológicas independentes do sujeito que as enuncia. Mas, é na medida em que distingue a sua imagem no espaço da cidade, do poema e da casa, que essas realidades se tornam próprias e conformam um corpo.

Finalmente, Desterro conclui com um fragmento de 'L'innommable (1953), de Samuel Beckett, arrematando, assim, com uma máxima que se reafirma na hesitação: “ (...) é preciso dizer palavras, enquanto houver, é preciso dizê-las, enquanto elas me encontrem, [...] é preciso continuar, não posso continuar, vou continuar" (s/n). A catarse poética que propõe Camila Assad não deixa de ser um jogo de referências intertextuais e de leituras assimiladas que, através de uma prática interdisciplinar, se conjugam para assinalar uma 
fissura ou um erro de cálculo no sistema. Os vários processos de apropriação, transcrita e reescrita, incidem nesses desequilíbrios para oferecer uma alternativa. O espaço da cidade líquida espalha-se no poema e encontra, em possíveis coletividades, ilhas e refúgios que tornam visíveis outros corpos da escrita. Mesmo sabendo que "é mais difícil ser Tereza do que ser Pagu" (idem: 20), mesmo sendo cientes de que todo desterro acarreta uma renúncia e, portanto, uma perda, Assad também mostra que toda queda é também um novo princípio.

\section{NOTAS}

* Isaac Giménez é doutorando no Programa de Pós-Graduação de Literatura e culturas latino-americanas no Departamento de Espanhol e Português da Universidade de Califórnia, Los Angeles. Mestre em literatura brasileira pala UCLA e licenciado em Estados da Tradução (inglês e português) pela Universidade de Granada (UGR). Pesquisa a poesia brasileira dos séculos XX e XXI e, em especial, construções autorias marginais.

${ }^{1}$ Não por acaso, Camila Assad escolhe os versos a seguir para introduzir Desterro: "Quatro mil mulheres, no cárcere, / e quatro milhões - e já não sei a conta, / em cidades que não se dizem / em lugares que ninguém sabe". Não podemos ignorar que, além de Cecília Meireles ser uma das poucas autoras destacadas dentro do cânone modernista brasileiro, também reivindicou explicitamente o seu direito de ser poeta.

${ }^{2}$ Além de ser considerado o primeiro crítico da modernidade, Baudelaire foi o primeiro em teorizar sobre a figura do flâneur. O fragmento que resgata Camila Assad pertence ao texto "O artista, homem do mundo, homem das multidões e criança", incluído em Le peintre de la vie moderne [O pintor da vida moderna], publicado orginalmente em 1983 no jornal francês Le Figaro como uma coleção de ensaios dividida em três partes. Como sabemos, as contribuições teóricas de Walter Benjamin a respeito da obra de Baudelaire foram fundamentais para desenvolver este conceito ligado aos projetos de modernização e industrialização que viveram as cidades europeias a partir do século XIX. Nesta linha, destacam também os trabalhos de Franz Hessel - Spazieren in Berlin [Passeios por Berlim], 1929 - e de Léon-Paul Fargue - Le Piéton de Paris, 1939 -. 
${ }^{3}$ Além disso, o filósofo acrescenta que a palavra grega graphein significa gravar (graven). Portanto, orginalmente escrever era fazer uma inscrição sobre um objeto, ou seja, inscrever (Vila-Fortes 2019: 139).

4 "ele [D.] me disse ["de um jeito bonito"] que há trinta formas / de matar um porco / e eu respondo que há muita solidão / em qualquer esquina / de qualquer cidade" (Assad 2019: 34).

${ }^{5}$ Camila Assad toca em questões existenciais de forma mais explicita na sua obra anterior, eu não consigo parar de morrer.

${ }^{6}$ Já os primeiros versos do poema ilustram a forma fugitiva na que o eu poético aparece mobilizado: "uma única pessoa conseguiu enganar as trevas / não fui eu / não foi deus / tampouco o diabo / uma uma uma pessoa só / conseguiu enganar as trevas / também não sei bem quem foi” (idem: 47).

${ }^{7}$ Reproduzo a seguir o diálogo: "x: Se eu ganhasse todos aqueles milhões na Mega-Sena ia / comprar uma casona na Praia Grande / z: Deixa de ser ridícula, se você ganhasse tanto dinheiro / assim podia comprar uma casona em Santos [seta transversal ondulante descendente] $104 \mathrm{~km} / /$ na minha época food truck era doginho" (idem: 47).

8 "Talvez o silêncio amplifique a voz, / talvez a dor acrescente ondas ao mar / e talvez o mar seja hoje apenas uma reflexão / de uma ruína // e não me importam os cães de raça / e não me importam as babershops / e não me importam os caixas eletrônicos / espalhados pela cidade / ou a arte de rua pulverizada / nos becos dizendo: / Destroy what destroys you / mas eu me destruo." (Ibidim: 53).

${ }^{9}$ Esta citação pertence ao texto "Objeto e fim da presente obra", publicado originalmente em novembro de 1926 na Revista do Brasil, e, incluído como prefácio da primeira edição de Serafim Ponte Grande (1933). Também aparece na abertura de Delírio de Damasco (2012) de Verónica Stigger.

${ }^{10}$ Autor de Uncreative writing: Managing language in the digital age (2011) e de trabalhos como The Weather (2005), Traffic (2007) e Sports (2008).

${ }^{11}$ Palavras da autora conforme aparecem referidas na contracapa de Delirio em Damasco.

${ }^{12}$ A pesquisadora lembra, igualmente, dos recortes de vozes em Oswald de Andrade, da composição por colagem d' O homem e o cavalo (1934), e da produção dos anos 1920 de modo geral.

13 "O conceito da deriva está estreitamente ligado ao reconhecimento dos efeitos de natureza psicogeográfica e à afirmação de um comportamento lúdico-constructivo, que se opõe de forma geral às noções clássicas de viagem e de passeio" [a tradução é minha]. O texto de Guy Debord "Théorie de la dérive” foi publicado originalmente em Les Lèvres Nues \#9 (novembro de 1956) e, despois, em Internationale Situationniste \#2 (dezembro 1958).

${ }^{14}$ Os Letristas, e posteriormente os Situacionistas, usaram o "método de propaganda" para ilustrar a questão da psicogeografia de "centros", intersecções de onde partem várias descidas psicogeográficas, simbolizadas pelas setas vermelhas.

${ }^{15}$ Em Can't and Won't, uma coleção de micro-histórias publicadas em 2014 por Farrar, Straus \& Giroux.

16 "Recuperação da adolescência" aparece publicado na primeira coletânea de Ana Cristina C, poeta, tradutora e crítica literária associada com a geração de poetas marginais (cariocas) da década de 1970. O texto original diz: "é sempre mais difícil / ancorar um navio no espaço".

${ }^{17}$ Termo cunhado pelo sociólogo humanista polaco Zygmunt Bauman para designar o tempo presente em lugar de utilizar pós-modernidade. A metáfora do "líquido" ou "fluidez" condensa a ideia de constante mudança, a vulnerabilidade, instabilidade, e o temporário da sociedade de consumo da segunda metade do século XX. 
Ao contrário da modernidade sólida, quando o maior receio era a não pertença ou adequação à norma vigente, a sobrevalorização do individualismo e libertação dos laços sociais e institucionais da modernidade liquida levam ao medo da alteridade e das diferenças. A cidade líquida revela-se como um espaço distópico onde os encontros são fugazes e o maior prazer é consumir. A "cidade líquida" prefere a velocidade à permanência, a mudança à solidez. Tudo nela é instável: a habitação, o trabalho, os laços familiares e afetivos. Os eventos são instantâneos, os movimentos e ligações são passageiros, o momento presente é dominado pela espetacularização, os happenings oficiais e corporativos pontuam a vida citadina. Neste sentido, acho muito reveladora a citação de Felipa Leal, que introduz a seção "Inesgotáveis" de Desterro: "A cidade talvez fosse de água. Como sobreviver a uma cidade líquida? / (Eu tentava sustentar-me como um barco)” (69). Na cidade líquida, resistir é também se tornar barcos-territórios para outros. Como o jogo da amarelinha, o poema seria em Desterro apenas um alto entre salto e salto. Para mais informação, consultar Liquid modernity (2000), de Zygmunt Baumam.

${ }^{18}$ A performance de "What makes a poem a poem?" de Charles Bernstein, ou a "60-second lecture" proferida na Universidade de Pensilvânia em abril de 2004, está disponível em: https://www.youtube.com/ watch?v=auhINfzRcyY.

\section{BIBLIOGRAFIA}

Andrade, Oswald de (1933), "Objeto e fim da presente obra." Serafim Ponte Grande. 9a edição. São Paulo, Globo.

Assad, Camila (2019), Desterro, Juiz de Fora, Edições Macondo.

Baudelaire, Charles (2006), Poesia e prosa, tradução de Ivan Junqueira, Rio de Janeiro, Nova Aguilar [1863].

Baumam, Zygmunt (2000), Liquid modernity, Cambridge, Polity Press \& Blackwell Publishers.

Bernstein, Charles (2004), “What makes a poem poem?”, 60-Second Lecture, University of Pennsylvania, April 2, <https://www.youtube.com/watch?v=auhINfzRcyY>, (último acesso em 15/03/2021)

Bracher, Beatriz (2007), Antonio. São Paulo, Editora 34.

Cesar, Ana Cristina (2013), Cenas de abril, São Paulo, Companhia das letras [1979].

Davis, Lydia (2014), Can't and Won't stories, New York, Farrar, Strauss and Giroux.

Debord, Guy (1956), "Théorie de la dérive", Les Lèvres nues, n 8, reimpresso em Internationale Situationiste, $\mathrm{n}^{\circ}$ 2, https://www.larevuedesressources.org/IMG/_ article_PDF/article_38.pdf, (último acesso em 15/03/2021). 
Debord, Guy / Jorn, Asger (1957), The Naked City: Illustration de hypothése des plaques tournantes en psychogéographique, G.-E. Debord. Permild \& amp; Rosengre, $<$ https://www.frac-centre.fr/_en/art-and-architecture-collection/debord-guy/thenaked-city-317.html?authID=53\&ensembleID=705>, (último acesso em 15/03/2021).

Librandi-Rocha, Marília (2015), "Escritas de ouvido na literatura brasileira." Literatura e sociedade, n. 19, pág. 131-148.

Pucheu, Alberto (1993), Na cidade aberta, Rio de Janeiro: EdUERJ.

Silveira Ribeiro, Gustavo (2017), "Interromper o instante, interrogar o agora: poesia, política e pensamento em Alberto Pucheu", Estudos de literatura brasileira contemporânea, n. 50, pág. 196-204, <http://ojs.bce.unb.br/index.php/estudos/ article/view/24141/17241>, (último acesso em 15/03/2021).

Stigger, Veronica (2012), Delírio em Damasco, Florianópolis, Cultura e Barbárie.

Süssekind, Flora (2013), "Objetos verbais não identificados: um ensaio de Flora Süsssekind”, O Globo, <https://blogs.oglobo.globo.com/prosa/post/objetosverbais-nao-identificados-um-ensaio-de-flora-sussekind-510390.html>, (último acesso em 15/03/2021).

Vila-Forte, Leonardo (2019), Escrever sem escrever. Literatura e apropriação no século XXI, Rio de Janeiro, Editora PUC-Rio, e-book. 